\title{
OBITUARIES
}

\section{Sir Harold Hartley}

Sir Harold Hartley died on 9 September 1972 , at the age of 94 , in full possession of his remarkable mental powers. Up to the last he was busy every afternoon receiving visitors, advising, and continuing literary work. His witty speech at a Royal Society Glub dinner to celebrate his ninetieth birthday is proor of his undiminished zest in life (Notes and records of the Royal Society, xxiv [1969], 146). Few people have had such a varied career which was so successlul at every stage.

He entered Balliol College, Oxford, as a scholar from Dulwich and obtained a First Class in the Final Honour School of Chemistry in Igor. His tutor, Sir John Conroy, died just at this time, and the college immediately appointed him to a tutorial Fellowship with responsibility for teaching in the joint Balliol-Trinity college laboratory. He was first interested in crystal chemistry, but in 1904 a wider field opened out. In a reorganization of laboratory teaching he secured for the Balliol-Trinity laboratory, with great foresight, the newly developing subject of physical chemistry, and this remained the centre of such instruction for all chemistry students until the University erected the Physical Chemistry Laboratory in 1940. The reputation of the college laboratory is too well known to be detailed here; see Notes and records of the Royal Society, xxv (1970), 227. Among other researches, Hartley began the study of electrolyte conductivity of salt solutions, especially in organic solvents.

Soon after the First World War broke out Hartley was a captain in the army, and when gas attacks started he was picked out to be chemical adviser to the Third Army. Rapidly rising in the service, he left at the end of the war as a Brigadier-General with awards. The post-war period, back at Oxford, was for him a time of concentrated teaching and research, with constant encouragement given to his pupils, of whom C. N. Hinshelwood (afterwards Sir Cyril Hinshelwood, O.M., P.R.S.) was the most notable. In research he cultivated extreme precision and perfection of technique; in tutorials he attempted little formal instruction but, by well-chosen comments, put his students on their mettle and made them think on a broad scale. All those who received this treatment continue to remember it with gratitude and affection.

In 1930 there was an unexpected turn in his affairs. Whether he could not see much chance of advancement at Oxford, or that the brilliance of Hinshelwood in research made him feel that here was an ideal head for the laboratory, or whether experiences he had already received of industry after the war drew him away, one cannot say; but Lord Stamp persuaded him to become director of scientific research of L.M.S. railways. For the next fifty years his wise counsels were in demand in a wide range of committees, in practically all of which he acted as chairman. These include Railway Air Services, the Executive Council of the World Power Conference, the Fuel Research Board, various Second World War committees, British Overseas Airways Corporation, the Electricity Supply Research Council, the Energy Commission of the Office of European Economic Co-operation, and the Duke of Edinburgh's Study Conference on Human Problems of Industrial Communities. He also acted as president of the British Association (1950), of the Institute of Chemical Engineers, and of the Society of Instrument Technology. As a consultant, in his eighties, he delivered the Romanes Lecture in 1964 and received the Kelvin Medal for services to science and technology in 1966 .

Hartley's manner endeared him to all those he met. He always listened 
courteously to anyone, especially young people. His wonderful judgement of men and of affairs was the secret of his career. When he wanted something done he could charm whoever he had fixed on to undertake the task, and could see, too, that it was properly carried out.

A strong sense of continuity in things made him set a high value on the history of science. In the early days of the setting up of what is now the Museum of the History of Science at Oxford there were serious difficulties to be overcome. The University Press was reluctant to give up the use of the Old Ashmolean Building, and the Gurator of the collections, R. T. Gunter, had the unhappy knack of antagonising both opponents and friends, Hartley was the man to smooth the path towards acceptance by the University of Gunter's use of the building.

Hartley was appointed editor of $\mathcal{N}$ otes and records of the Royal Society in $\mathbf{1 9 5 2}$ and maintained its high standard of output for eighteen years. His portrait by Hinshelwood appears in volume xxvi (197I), 2. He also served the Royal Society as chairman of the British National Committee of the History of Science, Medicine, and Technology, and also of the Scientific Manuscripts Committee. Articles by him on Berzelius, Dalton, Davy, and Ramsay, appear in the Society's publications, and he was entirely responsible for deciding on contributors to the Tercentenary Volume The Royal Society, its origins and founders ( 1960 ) by his unique method described above: ' $I$ have put you down to write ... etc.' He always wished he could find time to write more on history, but his Humphry Davy and Studies in the history of chemistry were left to his old age. As a young don he had collected nineteenth-century books and papers of importance; these he arranged to be taken into the library of the Royal Society. What the Society thought of him will be found expressed in the reference given in the first paragraph of this article.

E. J. BoweN

\section{L. WHYTE}

Lancelot Law Whyte, M.C., died in hospital on 14 September 1972, after a short illness. Lancelot Whyte was a well-known member of our Society, although his interests were perhaps more philosophical than historical. He was born on 4 November 1896 , the youngest of eight children of a renowned Presbyterian preacher and religious writer, the senior minister of United Free St George's, Edinburgh. In Focus and diversions (1963) Lancelot Whyte gave an amusing description of life in his Edinburgh home. In I 906 his mother sent him to J. H. Badley's 'agnostic and rationalistic co-educational Bedales', as far from Scottish Calvinism as she could. From school at Bedales he went into the army in I9I5, and shortly afterwards was sent to the Somme, and later to Arras. In France, as a Lieutenant in the Artillery, he was seriously wounded and was awarded the Military Cross.

After the war Whyte was able to take up a deferred senior scholarship at Trinity College, Cambridge. His interest in the constitution of matter was lifelong, and while still at school he had been introduced to Boscovichean atomism by Rouse Ball. (Note Whyte's Roger Joseph Boscovich, published in I 96I.) He stayed on at Cambridge to do research in physics under Rutherford's 'wise and severe discipline of complete freedom', and after a period at Göttingen, where he attended the lectures of Bohr, he returned to the Cavendish Laboratory, where he worked with Blackett and Hartree. He was constantly disturbed by war memories, however, and in 1923 he left Cambridge to work in industry. 